\title{
Radiation dimming induced modifications in radiation utilization of wheat (Triticumaestivum) crop
}

\section{JOYDEEP MUKHERJEE* , BRIJESH YADAV, V.K. SEHGAL, D.K. DAS, PRAMEELA KRISHNAN and RAJ KUMAR DHAKAR}

\author{
Division of Agricultural Physics, ICAR-Indian Agricultural Research Institute, New Delhi 110012, India \\ *Corresponding author: joydeep.icar@gmail.com
}

\begin{abstract}
Global dimming has many environmental and climatic implications. India has also experienced a steady and continuous radiation dimming since 1960s due to increasing load of dust and aerosol in the atmosphere. Radiation interception, temperature, humidity and wind profile are altered under reduced light condition which are determining factor for crop phenology, leaf area index, biomass production, grain yield and radiation use efficiency of crops. In this experiment, three wheat cultivars (HD 2967, WR 544 and PBW 502) were grown under five solar radiation treatments i.e. R1 (no shading), R2 (20\% shading), R3 (35\% shading), R4 (50\% shading) and R5 (75\% shading) during rabi season of $2014-15$ and 2015-16 at research farm of ICAR-Indian Agricultural Research Institute (ICAR-IARI), New Delhi to study the effect of radiation dimming on performance of selected wheat cultivars. In both the years the canopy temperature of wheat from crop vegetative stage to maturity was decreased with increase of shading level. The effect of reduced solar radiation significantly decreased the biomass production and yield.The radiation use efficiency (RUE) for biomass was increased due to shading treatments whereas the RUE for yield decreased with radiation reduction. The RUE for yield was the highest for no shading treatment ( 0.85 and $0.75 \mathrm{~g} \mathrm{MJ}^{-1}$ in $2014-15$ and $2015-16$, respectively). Among the cultivars, the radiation use efficiency for biomass as well as yield was the highest in HD 2967 followed by WR 544 and PBW 502 , respectively.
\end{abstract}

Key words: Radiation use efficiency (RUE), PAR, radiation dimming, wheat

Increase in aerosol load in the atmosphere due to rapid industrialization, urbanization, increased fossil fuel burning as well as some natural phenomena like volcanic activities and forest fire has a major impact on the climate in recent years. The aerosols reduce the global solar radiation reaching the earth's surface which is the primary energy source for sustenance of life on earth. In present scenario, global dimming (reduction of global radiation) has received prominent attention because of its various climatic and environmental implications. Since solar radiation is one of the most important climate factors that regulate crop growth and development, global dimming has become a new challenge to crop production (Stanhill and Cohen, 2001; Mercadoet al., 2009 and Manikandanet al., 2018). Several researcher have reported a continuous and steady light dimming in India since 1960s (Wild et al., 2005; Ramanathanet al., 2005, Mu et al., 2010 and Mukherjee et al.,2014 and 2015).Kumariet al. (2007) observed a decreasein global solar radiation $\left(-0.86 \mathrm{~W} \mathrm{~m}^{-2}\right)$ during the period 1981-2004. The declining trend of a global radiation over India was $0.6 \mathrm{~W} \mathrm{~m}^{2}$ year $^{-1}$ during $1971-2000$ and $0.2 \mathrm{~W}$ $\mathrm{m}^{2}$ year $^{-1}$ during 2001-2010. This global dimming is mainly due to increasing cloud coverage and aerosol concentration in atmosphere. The cloud and aerosol content, reduces up to $10 \%$ of solar radiation over oceans and about $10-20 \%$ over land by the process of absorption and scattering. Hence, this cause cooling over land and heating the atmosphere (Singh et al., 2005). Plant growth and development is adversely affected under reduced light condition. However, the crop scientists also realized that radiation use efficiency(RUE) is higher for diffuse radiation than for direct radiation (Healey et al., 1998; Bhagatet al., 2017). Radiation interception, temperature, humidity and wind profile are altered under reduced light condition which are determining factors for crop phenology, growth, biomass production, RUE and grain yield of wheat. Therefore, this study was undertaken to understand the radiation use efficiency of some wheat cultivars reduced solar radiation condition. 


\section{MATERIALS AND METHODS}

\section{Site characterization}

The experiment was conducted on wheat crop during rabi season of 2014-15 and 2015-16 at research farm of ICAR-Indian Agricultural Research Institute (ICAR-IARI), New Delhi $\left(28^{\circ} 37^{\prime} \mathrm{N}\right.$ latitude, $77^{\circ} 09^{\prime} \mathrm{E}$ longitude). The surface soil of the experiment site is sandy loam with $64 \%$ sand, $16.8 \%$ silt and $19.2 \%$ clay. The site has bulk density $1.58 \mathrm{Mg} \mathrm{m}^{-3}, \mathrm{pH} 7.3$, organic carbon 0.47 percent, available nitrogen $170.6 \mathrm{~kg} \mathrm{ha}^{-1}$, available phosphorus $18.6 \mathrm{~kg} \mathrm{ha}^{-1}$ and available potassium $275.0 \mathrm{~kg} \mathrm{ha}^{-1}$.

\section{Weather during crop growth period}

The weather data recorded from the IARI agrometeorological observatory showed that the during rabi season of 2014-15, weekly mean maximum temperature ranged between $15.0^{\circ} \mathrm{C}$ and $36.5^{\circ} \mathrm{C}$ while, during $2015-16$, the weekly maximum temperature ranged between $17.04^{\circ} \mathrm{C}$ to $40.7^{\circ} \mathrm{C}$. The weekly mean minimum temperature during rabi season ranged from $3.3^{\circ} \mathrm{C}$ in $52^{\text {nd }}$ standard meteorological week (SMW) to $20.4^{\circ} \mathrm{C}$ in $16^{\text {th }} \mathrm{SMW}$ in 201415 while it ranged between $2.4^{\circ} \mathrm{C}\left(51^{\text {st }} \mathrm{SMW}\right)$ and $21.9^{\circ} \mathrm{C}$ (16 $6^{\text {th }}$ SMW) during 2015-16. The seasonal rainfall of $314 \mathrm{~mm}$ was received during rabiseason of 2014-15. But in the following year the rainfall was much lower $(22 \mathrm{~mm})$ during the same period. Total pan evaporation during entire rabi season were $91.1 \mathrm{~mm}$ and $94.7 \mathrm{~mm}$ during 2014-15 and 2015-16, respectively. The weekly mean bright sunshine hours ranged between 1.1 hours ( $\left.4^{\text {th }} \mathrm{SMW}\right)$ to 9.6 hours $\left(12^{\text {th }}\right.$ SMW) during the rabi season of 2014-15where the same varied between 0.2 hours ( $\left.3^{\text {rd }} \mathrm{SMW}\right)$ to 9.0 hours $\left(15^{\text {th }} \mathrm{SMW}\right)$ in 2015-16.

\section{Experimental details}

In this experiment, three wheat cultivars (HD 2967, WR 544 and PBW 502) were grown under five solar radiation treatments i.e. R1 (no shading), R2 (20\% shading), R3 (35\% shading), R4 (50\% shading) and R5 (75\% shading) during rabi season of 2014-15 and 2015-16. In this experiment split plot design was followed with three replications in $5 \mathrm{~m}$ $\times 3 \mathrm{~m}$ plots. Adose of 120:60:60 $\mathrm{kg} \mathrm{ha}^{-1}$ of N:P:K was applied (three split dose of $\mathrm{N}$ as basal, CRI and flowering).

\section{Shading technique}

Shading nets were used for artificially reduction in solar radiation. Four different types of shading nets, $20 \%$, $35 \%, 50 \%, 75 \%$, (on the basis of their opening size) were used. Nets were installed on $13^{\text {th }}$ January and $10^{\text {th }}$ January for the year 2014-15 and 2015-16, respectively after tillering stage to cover the plots.

\section{Observations and analysis}

The observations included canopy temperature, global solar radiation and photosynthetically active radiation (PAR) during active growth phase (61 to 128 days after sowing). The canopy temperature was measured at 14:00 hour at 10 day interval using hand-held infrared thermometer (AG-42, Telatemp Crop., USA) with $8^{\circ}$ field of view.

Global solar radiation was measured using cosine corrected pyranometer (Model: LI-200R, LICOR Inc., Lincoln, NE, USA). The absorbed fraction of photosynthetically active radiation (fPAR) was computed in daily basis from the PAR balance components observed from the treatment plots using Line quantum sensor LI-191SA (LICOR Inc., Lincoln, NE, USA). The daily intercepted PAR (IPAR) was calculated by multiplying daily incident PAR with corresponding daily fraction of absorbed PAR (fIPAR) and integrated over the entire growth period. Finally, the radiation use efficiency (RUE) was calculated for grain and biomass separately, by using following formula:

$$
\begin{aligned}
& \operatorname{RUE}_{\mathrm{b}}\left(\mathrm{g} \mathrm{MJ}^{-1}\right)=\text { Biomass } / \text { TIPAR } \\
& \operatorname{RUE}_{\mathrm{y}}\left(\mathrm{g} \mathrm{MJ}^{-1}\right)=\text { Grain yield } / \text { TIPAR }
\end{aligned}
$$

The significance of difference among the treatments and their interactions with respect to the observed parameters was tested using analysis of variance as applicable to split plot design, using Statistical Analysis System (SAS).

\section{RESULTS AND DISCUSION}

\section{Global solar radiation}

Global solar radiation was significantly reduced in all the radiation reduction treatments in both the seasons of 2014-15 and 2015-16. During rabi season of 2014-15, the lowest global solar radiation $\left(106.78 \mathrm{~W} \mathrm{~m}^{-2}\right)$ was observed in $\mathrm{R} 5$ (75\% radiation reduction) as compared to $188.2 \mathrm{~W}$ $\mathrm{m}^{-2}$ in $\mathrm{R} 4$ (50\% radiation reduction), $293.3 \mathrm{~W} \mathrm{~m}^{-2}$ in $\mathrm{R} 3(35 \%$ radiation reduction) and $469.5 \mathrm{~W} \mathrm{~m}^{-2} \mathrm{R} 2(20 \%$ radiation reduction) on 61 DAS (Table 1). Global solar radiation followed the similar trend during rabi of 2015-16. It was significantly reduced under $\mathrm{R} 5$ ( $75 \%$ radiation reduction) in comparison with other reduced radiation level treatments. The lowest value $\left(102.1 \mathrm{~W} \mathrm{~m}^{-2}\right)$ of global solar radiation was recorded in R5 treatment (Table 2). Reduction of solar radiation inside shades is decreased progressively with decrease of mesh size of nets. 
Table 1: Global solar radiation ( $\mathrm{W} \mathrm{m}^{-2}$ ) under different radiation reduction levels of wheat crop during rabiseason 2014-15 and 2015-16 (Shading treatments: R1=Control, R2=20\% Shading, R3 $=35 \%$ Shading, $4=50 \%$ Shading, R5 $=75 \%$ Shading)

\begin{tabular}{|c|c|c|c|c|c|c|c|c|}
\hline \multirow[t]{2}{*}{ Treatments } & \multicolumn{8}{|c|}{ Days after sowing } \\
\hline & 61 & 68 & 75 & 82 & 96 & 103 & 110 & 128 \\
\hline \multicolumn{9}{|c|}{$(2014-15)$} \\
\hline R1 & 487.2 & 647.7 & 591.8 & 583.9 & 601.9 & 644.3 & 692.6 & 781.5 \\
\hline $\mathrm{R} 2$ & 369.6 & 517.7 & 495.1 & 481.2 & 491.8 & 481.1 & 504.9 & 602.9 \\
\hline R3 & 314.8 & 403.2 & 359.2 & 382.1 & 407.1 & 415.1 & 422.9 & 542.4 \\
\hline R4 & 201.0 & 298.6 & 242.0 & 287.9 & 328.8 & 320.9 & 328.4 & 353.4 \\
\hline R5 & 106.8 & 178.5 & 155.7 & 150.0 & 151.1 & 157.5 & 194.5 & 187.9 \\
\hline $\mathrm{CV} \%$ & 6.2 & 6.3 & 6.2 & 8.4 & 10.5 & 5.3 & 8.5 & 6.8 \\
\hline \multicolumn{9}{|c|}{$(2015-16)$} \\
\hline $\mathrm{R} 1$ & 469.5 & 488.1 & 576.9 & 576.2 & 637.0 & 637.6 & 703.4 & 792.7 \\
\hline $\mathrm{R} 2$ & 354.9 & 356.3 & 448.0 & 472.2 & 414.3 & 508.6 & 508.3 & 569.7 \\
\hline R3 & 293.3 & 258.0 & 374.9 & 379.9 & 335.5 & 433.6 & 377.2 & 495.4 \\
\hline R4 & 188.2 & 198.6 & 260.2 & 246.3 & 238.4 & 297.9 & 307.7 & 349.1 \\
\hline R5 & 102.1 & 119.1 & 147.4 & 139.3 & 140.2 & 154.4 & 179.2 & 182.6 \\
\hline CV\% & 3.2 & 4.1 & 12.1 & 7.3 & 8.7 & 4.4 & 3.8 & 4.3 \\
\hline
\end{tabular}
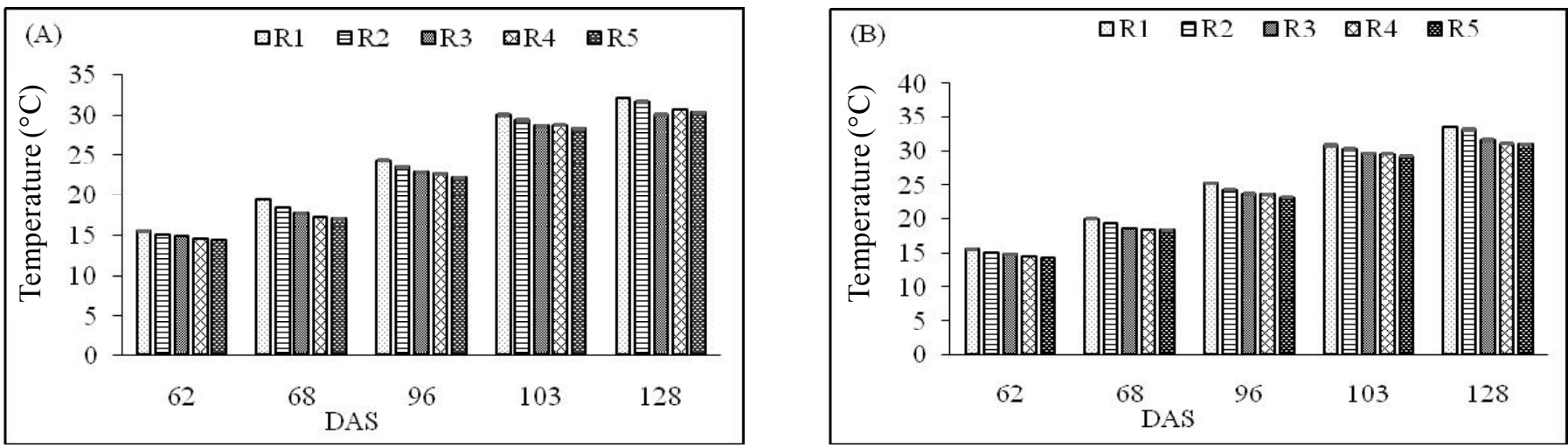

Fig. 1: Variation of canopy temperature under different radiation reduction levels of wheat crop during rabi season (A) 201415 and (B) 2015-16 (Shading treatments: R1=Control, R2=20\% Shading, R3 = 35\% Shading, R4 = 50\% Shading, R5 $=75 \%$ Shading. Varieties: V1 $=$ HD 2967, V2 $=$ WR 544 and V3 $=$ PBW 502)

\section{Canopy temperature}

The canopy temperature continuously increased up to crop maturity in both the years of study. The canopy temperature was significantly higher in control treatment (no radiation reduction) than that of the reduced radiation treatments. It was observed that at maturity stage (around $128 \mathrm{DAS})$, the canopy temperature was maximum in control treatment, $\mathrm{R} 1\left(32.1^{\circ} \mathrm{C}\right)$, followed by that of $\mathrm{R} 2\left(31.6^{\circ} \mathrm{C}\right), \mathrm{R} 3$ $\left(30.6^{\circ} \mathrm{C}\right), \mathrm{R} 4\left(30.3^{\circ} \mathrm{C}\right)$ and the lowest value was recorded from R5 $\left(30.0^{\circ} \mathrm{C}\right)$ (Fig. 1). Similar trend was also observed during the following year (2015-16).

In both season canopy temperature was decreased with increase of shading level. Bell et al., 2000 and Li et al. (2010) also reported that the canopy effective accumulated temperature was low inside the shade net, which confirm the results of present study.

\section{Biomass accumulation}

The observations showed that reduction of radiation 
Table 2: Variation of total IPAR (TIPAR), biomass radiation use efficiency ( RUE $_{b}$ ) and yield radiation use efficiency (RUE , $_{\mathrm{y}}$ during rabi season 2014-15 (Shading treatments: R1=Control, R2=20\% Shading, R3 = 35\% Shading, R4 = 50\% Shading, R5 =75\% Shading. Varieties: V1 = HD 2967, V2=WR 544 and V3= PBW 502)

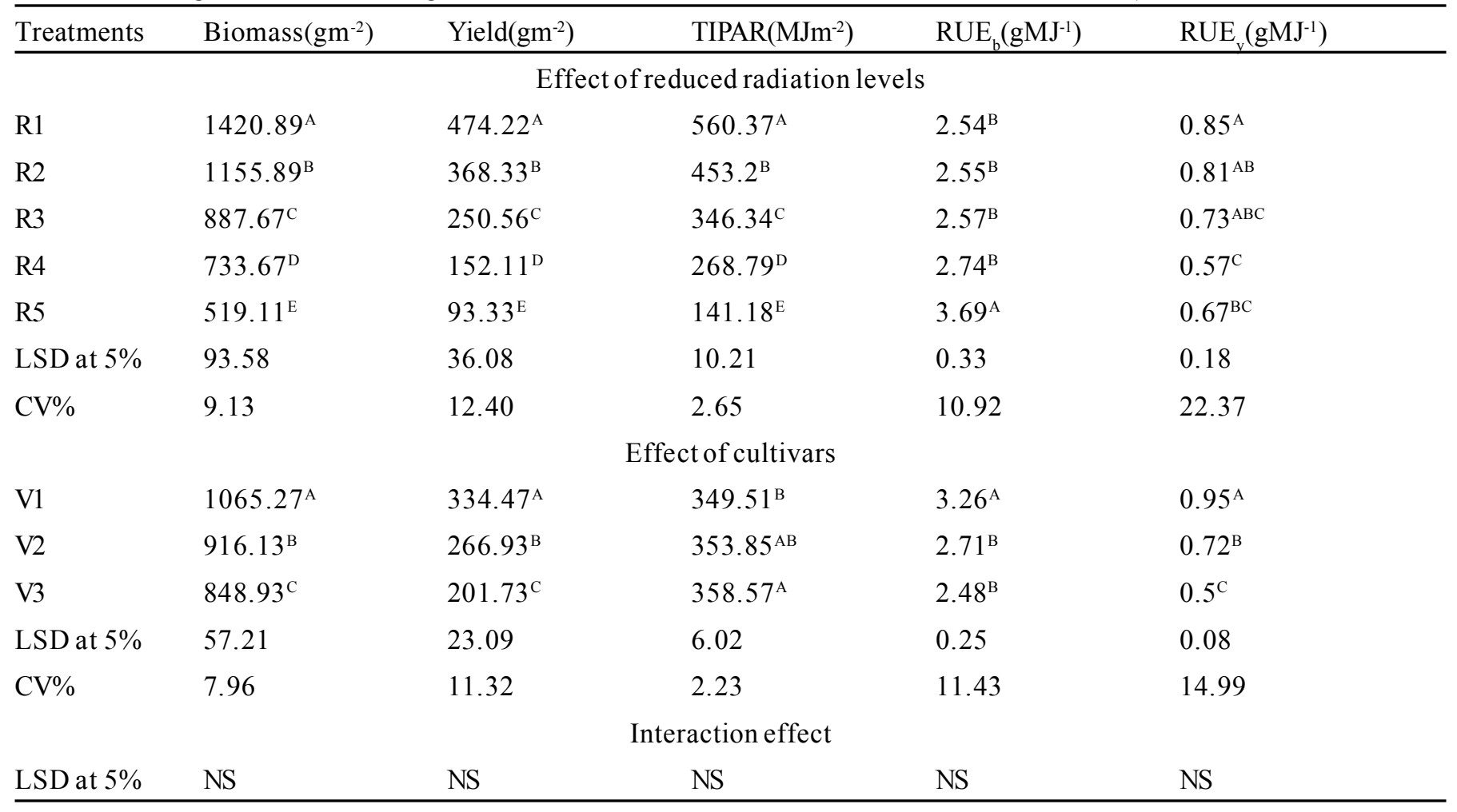
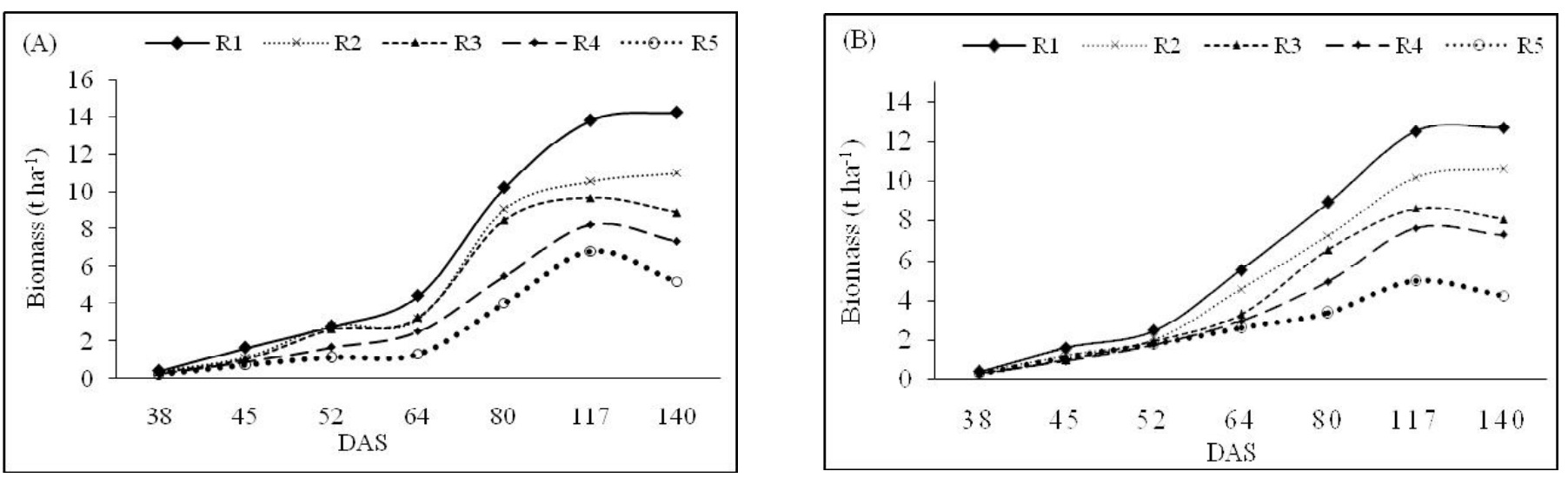

Fig.2: Effect of reduced solar radiation on above ground biomass of wheat crop during rabi season (A) 2014-15 and (B) 201516 (Shading treatments: R1=Control, R2=20\% Shading, R3 = 35\% Shading, R4 = 50\% Shading, R5=75\% Shading)

significantly influenced the temporal pattern of biomass production of wheat in all treatments during rabi season of 2014-15 and 2015-16. During 2014-15, the crop produced the highest biomass (14.21 tha $\mathrm{t}^{-1}$ ) in $\mathrm{R} 1$ (no reduced radiation) followed by 11.56 tha $^{-1}$ in $\mathrm{R} 2$ ( $20 \%$ reduced radiation), 8.88 tha $^{-1}$ in $\mathrm{R} 3$ (35\% reduced radiation), 7.34 tha $^{-1}$ in $\mathrm{R} 4$ (50\% reduced radiation) and 5.19 tha $^{-1}$ in $\mathrm{R} 5$ (75\% reduced radiation) at 140 DAS in rabi 2014- 15 . However, at other stages (64 DAS, 80 DAS and 117 DAS) R5 treatment showed lowest biomass accumulation among all the treatments (Fig. 2).

Similar result was found (Fig. 4) during 2015-16 crop season. The highest biomass (12.71 tha $\left.{ }^{-1}\right)$ accumulated in R 1 (no shading condition) followed by $10.65 \mathrm{tha}^{-1}$ in $\mathrm{R} 2,8.08$ $\mathrm{t} \mathrm{ha}^{-1}$ in $\mathrm{R} 3,7.28 \mathrm{t} \mathrm{ha}^{-1}$ in $\mathrm{R} 4$ and $4.22 \mathrm{t} \mathrm{ha}^{-1}$ in $\mathrm{R} 5$ under reduced radiation level. Different cultivars also recorded significant difference in biomass production. In both the 
Table 3: Variation of total IPAR (TIPAR), biomass radiation use efficiency $\left(\right.$ RUE $\left._{\mathrm{b}}\right)$ and yield radiation use efficiency $\left(\right.$ RUE $\left._{\mathrm{y}}\right)$ duringrabi season 2015-16 (Shading treatments: R1=Control, R2 $=20 \%$ Shading, R3 $=35 \%$ Shading, R4 $=50 \%$ Shading, R5 $=75 \%$ Shading. Varieties: V1 $=$ HD 2967, V2 = WR 544 and V3= PBW 502)

\begin{tabular}{|c|c|c|c|c|c|}
\hline Treatments & $\operatorname{Biomass}\left(\mathrm{gm}^{-2}\right)$ & Yield $\left(\mathrm{g} \mathrm{m}^{-2}\right)$ & TIPAR $\left(\mathrm{MJm}^{-2}\right)$ & $\operatorname{RUE}_{b}\left(\mathrm{gMJ}^{-1}\right)$ & $\operatorname{RUE}_{\mathrm{v}}\left(\mathrm{gMJ}^{-1}\right)$ \\
\hline \multicolumn{6}{|c|}{ Effect of reduced radiation levels } \\
\hline R1 & $1271.22^{\mathrm{A}}$ & $425.11^{\mathrm{A}}$ & $563.94^{\mathrm{A}}$ & $2.26^{\mathrm{B}}$ & $0.75^{\mathrm{A}}$ \\
\hline $\mathrm{R} 2$ & $1064.89^{\mathrm{B}}$ & $280.22^{\mathrm{B}}$ & $465.02^{\mathrm{B}}$ & $2.29^{\mathrm{B}}$ & $0.60^{\mathrm{AB}}$ \\
\hline R3 & $807.89^{\mathrm{C}}$ & $181.11^{\mathrm{C}}$ & $352.62^{\mathrm{C}}$ & $2.29^{\mathrm{B}}$ & $0.52^{\mathrm{BC}}$ \\
\hline R4 & $728.00^{\mathrm{C}}$ & $113.89^{\mathrm{D}}$ & $277.6^{\mathrm{D}}$ & $2.63^{\mathrm{B}}$ & $0.41^{\mathrm{C}}$ \\
\hline R5 & $422.22^{\mathrm{D}}$ & $51.33^{\mathrm{E}}$ & $137.05^{\mathrm{E}}$ & $3.08^{\mathrm{A}}$ & $0.37^{\mathrm{C}}$ \\
\hline LSD at $5 \%$ & 87.58 & 29.62 & 27.11 & 0.38 & 0.15 \\
\hline $\mathrm{CV} \%$ & 9.38 & 12.96 & 6.94 & 14.05 & 26.09 \\
\hline \multicolumn{6}{|c|}{ Effect of cultivars } \\
\hline V1 & $986.40^{\mathrm{A}}$ & $273.33^{\mathrm{A}}$ & $358.25^{\mathrm{A}}$ & $2.92^{\mathrm{A}}$ & $0.73^{\mathrm{A}}$ \\
\hline $\mathrm{V} 2$ & $857.47^{\mathrm{B}}$ & $196.60^{\mathrm{B}}$ & $359.64^{\mathrm{A}}$ & $2.5^{\mathrm{B}}$ & $0.48^{\mathrm{B}}$ \\
\hline V3 & $732.67^{\mathrm{C}}$ & $161.07^{\mathrm{C}}$ & $359.85^{\mathrm{A}}$ & $2.11^{\mathrm{C}}$ & $0.38^{\mathrm{C}}$ \\
\hline LSD at $5 \%$ & 64.31 & 10.95 & NS & 0.23 & 0.05 \\
\hline $\mathrm{CV} \%$ & 9.83 & 6.83 & 2.38 & 11.88 & 12.69 \\
\hline \multicolumn{6}{|c|}{ Interaction effect } \\
\hline LSD at $5 \%$ & NS & 35.69 & 15.10 & NS & NS \\
\hline
\end{tabular}

cropping seasons the cultivar, HD 2967 recorded the highest biomass followed by that of WR 544 and PBW 502, respectively (Table3 and 4).

\section{Radiation use efficiency (RUE)}

Total intercepted PAR (TIPAR) and radiation use efficiency (RUE) in account of biomass accumulation and yield of wheat crop were significantly influenced by reduction in radiation. In 2014-15, the TIPAR was the lowestin R5 (141.18 $\left.\mathrm{MJ} \mathrm{m}^{-2}\right)$ followed that of R4 (268.79 MJ $\left.\mathrm{m}^{-2}\right), \mathrm{R} 3\left(346.34 \mathrm{MJ} \mathrm{m}^{-2}\right), \mathrm{R} 2\left(453.20 \mathrm{MJ} \mathrm{m}^{-2}\right)$ as compared $560.37 \mathrm{MJ} \mathrm{m}^{-2}$ from R1 where no shading was given. In the following year also, the lowest TIPAR of $137.05 \mathrm{MJ} \mathrm{m}^{-2}$ was recorded under R5 as compared to that of $\mathrm{R} 4\left(277.6 \mathrm{MJ} \mathrm{m}^{-}\right.$ $\left.{ }^{2}\right), \mathrm{R} 3\left(352.62 \mathrm{MJ} \mathrm{m}^{-2}\right), \mathrm{R} 2\left(465.02 \mathrm{MJ} \mathrm{m}^{-2}\right)$ and R1 (563.94 $\left.\mathrm{MJ} \mathrm{m}^{-2}\right)$. The difference among the shading treatments were statistically significant.

The radiation use efficiency (RUE) on account of biomass accumulation in 2014-15 was significantly higher under R5 (3.69 $\left.\mathrm{g} \mathrm{MJ}^{-1}\right)$ than other treatments (Table 3). The lowest RUE for biomass was recorded from R1 treatment $\left(2.54 \mathrm{~g} \mathrm{MJ}^{-1}\right)$ where no shading was applied and the same was progressively increased with reduction in radiation level. On the other hand the RUE for yield was the highest in no-shading treatment $\left(0.85 \mathrm{~g} \mathrm{MJ}^{-1}\right)$ which was significantly higher than that of R2 $\left(0.81 \mathrm{~g} \mathrm{MJ}^{-1}\right), \mathrm{R} 3\left(0.73 \mathrm{~g} \mathrm{MJ}^{-1}\right), \mathrm{R} 5(0.67$ $\left.\mathrm{g} \mathrm{MJ}^{-1}\right)$ and $\mathrm{R} 4\left(0.57 \mathrm{~g} \mathrm{MJ}^{-1}\right)$.

The trend of RUE during 2015-16 was similar to that of the previous year. The RUE on account of biomass accumulation was the highest in R5 $\left(3.08 \mathrm{~g} \mathrm{MJ}^{-1}\right)$ which was significantly higher than that of R4 $\left(2.63 \mathrm{~g} \mathrm{MJ}^{-1}\right)$. The RUE was the lowest under R1 (2.26 $\left.\mathrm{g} \mathrm{MJ}^{-1}\right)$ which is statistically at par with R2 and R3 (both $2.29 \mathrm{~g} \mathrm{MJ}^{-1}$ ). But the RUE for yield was decreased with reduction in solar radiation following the pattern similar to the previous year the highest value being recorded from $\mathrm{R} 1\left(0.75 \mathrm{~g} \mathrm{MJ}^{-1}\right)$ and the lowest from R5 $\left(0.37 \mathrm{~g} \mathrm{MJ}^{-1}\right)$. This suggest that the grain formation was more severely affected by reduced reduction. The earlier reports also suggested that at initial stages of growth the photosynthates were accumulated to maintain the growth and vigour of the crop. But in later stages, the crops under shade could not able to accumulate much photosynthates (Vrkoc,1973).

The present study suggests that as the total seasonal incident radiation (TIPAR) was reduced under shade net condition, the biomass production and crop yield was significantly reduced. This resulted in lower RUEs inside the shades. Several researchers have observed higher radiation- 
use efficiency (RUE) for diffuse solar radiation as compare to direct solar radiation but the RUE was less under severe shades as shade reduces both direct as well as diffuse radiation (de Wit, 1965; Allen et al., 1974; Norman and Arkebauer, 1991; Sinclair et al., 1992; Rochette et al., 1996; Healey et al., 1998).

There was significant difference among the cultivars with respect to radiation use efficiency as recorded in both the years. In 2014-15 the RUE for biomass recorded by HD 2967, WR 544 and PBW 502 were 3.26, 2.71 and 2.48 $\mathrm{g} \mathrm{MJ}^{-}$ ${ }^{1}$, respectively, whereas the RUE for yield recorded by these varieties were $0.95,0.72$ and $0.50 \mathrm{~g} \mathrm{MJ}^{-1}$, respectively. In the second year the RUE in general was relatively lower than that of the previous year as associated with lower biomass as well as grain yield. In 2015-16, the RUE for biomass was the highest from HD 2967(2.92 $\left.\mathrm{g} \mathrm{MJ}^{-1}\right)$ followed by WR 544 (2.50 $\left.\mathrm{g} \mathrm{MJ}^{-1}\right)$ and PBW $502\left(2.11 \mathrm{~g} \mathrm{MJ}^{-1}\right)$. The RUE for yield was the highest in HD $2967\left(0.73 \mathrm{~g} \mathrm{MJ}^{-1}\right)$ as compared to WR $544\left(0.48 \mathrm{~g} \mathrm{MJ}^{-1}\right)$ and PBW $502\left(0.38 \mathrm{~g} \mathrm{MJ}^{-1}\right)$

\section{CONCLUSION}

The study showed that the incident global solar radiation was reduced by more than 20 to $75 \%$ under shade net of different mesh size. This has caused noticeable reduction of canopy temperature of wheat crop grown under the shade net. The biomass and grain yield were significantly reduced due to increased shading. Radiation use efficiency on account of biomass accumulation ( RUE $_{b}$ ) was increased under severe shading ( $75 \%$ shading) but the RUE with respect to grain yield ( RUE $_{y}$ ) was decreased due to reduction in radiation and reduction in grain yield under shading net.

\section{REFERENCES}

Allen Jr, L.H., Stewart, D.W. and Lemon, E.R. (1974). Photosynthesis in plant canopies: Effect of light response curves and radiation source geometry. Photosynthetica, 8: 184-207.

Bell, G.E., Danneberger, T.K. and McMahon, M.J. (2000). Spectral irradiance available forturfgrass growth in sun and shade. Crop Sci., 40:189-195.

Bhagat, K.P., Bal, S.K., Singh, Y., Potekar, S.V., Saha, S., Ratnakumar, P., Wakchaure, G.C. and Minhas, P.S. (2017). Effect of reduced PAR on growth and photosynthetic efficiency of soybean genotypes.J. Agrometeorol., 19(1): 1-9

de Wit.(1965). Photosynthesis of leaf canopies. Centre for
Agriculture Publication and Documentation, Wageningen, Germany. p.57.

Healey, K.D., Rickert, K.G., Hammer, G.L. and Bange, M.P. (1998). Radiation use efficiency increases when the diffuse component of incident radiation is enhanced under shade. Aust. J. Agric. Res., 49: 665-672.

Li, H., Jiang, D., Wollenweber, B., Dai, T. and Cao, W. (2010). Effects of shading on morphology, physiology and grain yield of winter wheat. Eur.J.Agron., 33:267-275.

Manikandan, N., Das, D.K., Mukherjee, J., Sehgal, V.K. and Krishnan. P. (2018). Extreme temperature and rainfall events in National Capital Region of India(New Delhi) in the recent decades and its possible impacts. Theor. Appl.Climatol.,DOI: 10.1007/s00704-018-2652-9

Mercado, L. M., Bellouin, N., Sitch, S., Boucher,O., Huntingford, C., Wild, M. and Cox, P. M. (2009). Impact of changes in diffuse radiation on the global land carbon sink. Nature, 458(7241):1014-1017.

Mu, H., Jiang, D., Wollenweber, B., Dai, T., Jing, Q. and Cao, W. (2010). Long term low radiation decreases leaf photosynthesis, photochemical efficiency and grain yield in winter wheat. J.Agron. Crop Sci., 196:38-47.

Mukherjee, J., Singh, G. and Bal, S.K. (2014). Radiation use efficiency and instantaneous photosynthesis at different growth stages of wheat (TriticumaestivumL.) in semi arid ecosystem ofCentral Punjab, India.J. Agrometeorol., 16(1): 69-77.

Mukherjee, J., Singh, S.S., Santosh Kumar.andIdris, M. (2015). Radiation use efficiency and yield of wheat crop grown under elevated $\mathrm{CO}_{2}$ and temperature in open top chamber in Patna, Bihar. J. Agrometeorol., 17(2): 158-164.

Norman, J.M. and Arkebauer, T.J. (1991). Predicting canopy light-use efficiency from leaf characteristics. Model. PlantSoil Syst., 31:125-143.

Ramanathan, V., Chung, C., Kim, D., Bettge, T., Buja, L., Kiehl, J. T. and Wild, M. (2005). Atmospheric brown clouds: Impacts on South Asian climate and hydrological cycle. Proc. National Acad. Sci. USA, 102(15):53265333.

Rochette, P., Desjardins, R.L., Pattey, E. and Lessard, R. (1996). Instantaneous measurement of radiation and water use efficiencies of a maize crop. Agron. J., 88:627-635.

Sinclair, T.R., Shiraiwa, T. andHammer, G.L.(1992). Variation 
in crop radiation-use efficiency with increased diffuse radiation. Crop Sci., 32:1281-1284.

Singh, S., Nath, S., Kohli, R. and Singh, R. (2005). Aerosols over Delhi during pre monsoon months: Characteristics and effects on surface radiation forcing. Geophy. Res. Lett., 32(13).

Stanhill, G. and Cohen, S. (2001). Global dimming: a review of the evidence for a widespread and significant reduction in global radiation with discussion of its probable causes and possible agricultural consequences. Agric.Forest Meteorol., 107(4):255-278.

Wild, M., Gilgen, H., Roesch, A., Ohmura, A., Long, C.N., Dutton, E.G. and Tsvetkov, A. (2005). From dimming to brightening: Decadal changes in solar radiation at Earth's surface. Science, 308(5723):847-850.

Received: December 2019; Accepted: July 2020 